\title{
Native microbial consortia improve maize shoot and root systems at early developmental stages in a seedbed assay
}

\author{
Consorcios de microorganismos nativos mejoran \\ los sistemas caulinar y radicular del maíz en etapas \\ tempranas de desarrollo en un ensayo de semillero
}

\author{
Carlos Esteban Guardiola-Márquez 1, Melina Lizeth Figueroa-Montes 1, Adriana Pacheco Moscoa 2, Carolina \\ Senés-Guerrero ${ }^{1}$ \\ ${ }^{1}$ Tecnológico de Monterrey, Escuela de Ingeniería y Ciencias. General Ramón Corona 2514, Colonia Nuevo México, C.P. 45138, \\ Zapopan, Jalisco, México \\ ${ }^{2}$ Tecnológico de Monterrey, Centro de Biotecnología-FEMSA, Escuela de Ingeniería y Ciencias. Av. Eugenio Garza Sada 2501 sur, C.P. \\ 64849, Monterrey, Nuevo León, México
}

\section{RESUMEN}

Antecedentes: La agricultura es uno de los principales contribuyentes a la degradación ambiental. Los microorganismos del suelo son esenciales para mejorar el crecimiento de las plantas, el rendimiento de los cultivos y la tolerancia al estrés.

Objetivo: Caracterizar la respuesta temprana del maíz en condiciones de semillero a consorcios nativos de microorganismos aislados de zonas áridas.

Métodos: Dieciséis hongos y 16 bacterias de suelos áridos fueron identificados por MALDI-TOF MS y verificados por características morfológicas. Se evaluaron diez biofertilizantes con réplicas $(n=100)$ en maíz bajo condiciones de semillero. Los consorcios se formularon basándose en caracteres promotores del crecimiento, incluyendo principalmente especies de Penicillium y Pseudomonas. Después de 45 días, los biofertilizantes se evaluaron midiendo altura de la planta y peso fresco de los brotes y raíces.

Resultados y Conclusiones: Penicillium y Pseudomonas fueron los géneros predominantes. Los consorcios bacterianos promovieron principalmente el desarrollo caulinar, mientras que la combinación de hongos y bacterias aumentó notablemente el desarrollo de las raíces. Ocho consorcios microbianos de zonas áridas tuvieron efectos positivos en la etapa temprana del desarrollo del maíz en condiciones de semillero en comparación con plantas no inoculadas.

Palabras clave: Agricultura sostenible, biofertilizante, microorganismos promotores del crecimiento de plantas, consorcios microbianos, microorganismos del suelo

\section{ABSTRACT}

Background: Agriculture is a major contributor to environmental and soil degradation. Soil microorganisms are essential to improve plant growth, crop yields and stress-tolerance.

Objective: To characterize maize early plant-response in a seedbed setting to native consortia of isolated microorganisms from arid zones.

Methods: Sixteen fungal and 16 bacterial isolates from arid soils were identified by MALDI-TOF MS and confirmed using morphological characteristics. Ten biofertilizers were tested in replicates $(n=100)$ in maize under seedbed conditions. Consortia were formulated based on growth promoting traits, including mainly Penicillium and Pseudomonas species. After 45 days, biofertilizers were evaluated according to plant height, and shoot and root fresh weight.

Results and Conclusions: Penicillium and Pseudomonas were the predominant genera identified. Most strains are potential candidates for biofertilizer formulation based on their growth promoting traits. Bacterial consortia mainly promoted plant caulinar development, while the combination of fungal and bacterial species markedly increased root development. Eight biofertilizer consortia from arid zones had positive effects at early developmental stage of maize under seedbed conditions compared to uninoculated plants.

Keywords: Sustainable agriculture, biofertilizer, plant growth promoting microorganisms, microbial consortia, soil microorganisms

\section{ARTICLE HISTORY}

Received 28 July 2020 / Accepted 29 November 2020

Published on line: 20 April 2021
CORRESPONDING AUTHOR

\4 Carolina Senés-Guerrero, carolina.senes@tec.mx

ORCID: 0000-0002-3089-6501 


\section{INTRODUCTION}

The global rise in human population is driving a steady increase in the demand for food as it will be necessary to increment its production by $70 \%$ in 2050, estimating that $90 \%$ of the growth of agricultural production will be possible by obtaining higher yields, meaning crop intensification (FAO, 2009; Mahanty et al., 2017; Carrington, 2018; Adisa et al., 2019). The conventional agricultural system is designed for massive food production, increasing yields and decreasing production costs at the expense of high energy consumption and excessive use of fertilizers, pesticides and water; consequently, degrading the environment through air and water pollution, soil depletion, and loss of soil ecosystems and biodiversity (Horrigan et al., 2002; Glick, 2014; DeLonge et al., 2016; Mahanty et al., 2017; ElGhamry et al., 2018; Kumari and Singh, 2019). Particularly, chemical fertilizers are extensively applied to sustain the growing demand for food. According to the FAO, worldwide consumption of chemical fertilizers was 191.98 million tons in 2019 (FAO, 2019), considering that plants use between $20 \%$ and $50 \%$ of the applied fertilizer, there is a high rate of fertilizer release into the environment (Drechsel et al., 2015; Tomer et al., 2016; Mahanty et al., 2017; El-Ghamry et al., 2018; Kumari and Singh, 2019).

The Intergovernmental Science-Policy Platform on Biodiversity and Ecosystem Services (IPBES) details that intensified cropping and rapid expansion of croplands have placed agriculture as the main driver of soil degradation (IPBES, 2018; Leahy, 2018). Soil degradation is one of the greatest environmental problems faced by humanity (FAO, 2015; IPBES, 2018; Watts, 2018; Kopittke et al., 2019); it is reported that $33 \%$ of the world's land and $52 \%$ of agricultural land are moderately or severely degraded (ELD, 2015; FAO, 2015), projecting that in the next 25 years soil degradation will reduce global food production by $12 \%$ to $50 \%$, increasing food prices by 30 \% (United Nations, 2010; ELD, 2015). Agriculture faces major challenges to improve food security and implement more sustainable and less harmful production strategies (FAO, 2009). Implementation of sustainable agriculture is a viable alternative to meet these challenges as it involves the development of cost effective, eco-friendly and high efficiency procedures (Malusá et al., 2012; DeLonge et al., 2016; Busby et al., 2017; Prasad et al., 2017; El-Ghamry et al., 2018;
Adisa et al., 2019; Elemike et al., 2019; Kumari and Singh, 2019). The use of biofertilizers is a very promising sustainable practice since they improve water use efficiency, increase crop yields from 10 to up to $40 \%$ (Bhardwaj et al., 2014), reduce chemical fertilization (35 to $50 \%$ ) without compromising crops yield (Kumar et al., 2009; Isfahani and Besharati, 2012; Aggani, 2013; Saeed et al., 2015a, b; Nurbaity et al., 2016; Guardiola-Márquez et al., 2019), and improve plant resistance to adverse environmental conditions (Jochum et al., 2019; Ojuederie et al., 2019). Beneficial microorganisms from biofertilizers colonize the rhizosphere and root system of the plant and promote growth through different mechanisms such as siderophores production, atmospheric nitrogen fixation, solubilization of minerals (phosphorus, potassium), and production of phytohormones (auxins, cytokinins, gibberellins) and enzymes (phosphatases, catalases) (Vessey, 2003; Bardi and Malusa, 2012; Malusa and Vassilev, 2014; Alori et al., 2017; Mahanty et al., 2017; El-Ghamry et al., 2018; Gouda et al., 2018).

Even though biofertilizers represent a promising alternative, most of them are produced from commercial microbial strains that may not be adapted to adverse climatic conditions, hindering their colonization and survival (Horrigan et al., 2002; Aggani, 2013; Gupta et al., 2015; Gouda et al., 2018). In this sense, the use of native communities of soil microorganisms is essential for the development of biofertilizers for arid environments. The efficiency of microbial inocula increases when native species of plant growth promoting (PGP) microorganisms are used as they show higher ability to increase crop yields and plant stress-resistance, greater resistance against pathogens and higher colonization rates since they have greater adaptability to local environmental conditions (Berruti et al., 2016; Emam, 2016; Sood et al., 2018). Also, several publications have shown that the use of microbial consortia as inocula is more effective to increase crop yields and growth promotion properties in plants, in comparison with individual strains (El-Afry et al., 2012; Wang et al., 2012; Naseem and Bano 2014; Kumar et al., 2016; Vurukonda et al., 2016; Ojuederie et al., 2019). A final consideration is that plants have different nutritional requirements at each developmental stage and microbial inocula represent a different metabolic expense for plants. Indeed, plant age can affect and change microbial communities (Roesti et al., 2006). Therefore, it 
is important to evaluate the effects of biofertilizers at different stages of plant development, being early stages important for plant establishment.

Hence, the objective of this study was to evaluate the early plant-response of maize (Zea mays) to isolated native fungal and bacterial consortia from arid zones in a seedbed setting.

\section{MATERIALS AND METHODS}

\section{Microbial selection and identification}

Microbial species were previously isolated from root and soil samples of six economically relevant crops: watermelon (Citrullus lanatus (Thunb.) Matsum. \& Nakai), onion (Allium cepa L.), walnut (Juglans regia L.), pepper (Capsicum annuum L.), alfalfa (Medicago sativa L.) and maize (Zea mays L.) from arid soils in northern Mexico. Crops were sampled at three different fields each, giving a total of 18 fields distributed in four towns located in the south center (Meoqui, Delicias and Saucillo) and one in south east (Camargo) of the State of Chihuahua. These towns exhibit extreme semiarid climate, average daytime temperature is $32{ }^{\circ} \mathrm{C}$ and rainfall is $328 \mathrm{~mm}$ per year (INEGI, 2018).

Isolates were screened for $\mathrm{N}$-fixation, and phosphate and potassium solubilization. $\mathrm{N}$-fixation was determined on $\mathrm{N}$-free solid malate medium (Nfb) (malate: $5 \mathrm{~g}$ $\mathrm{L}^{-1}, \mathrm{KOH}: 4 \mathrm{~g} \mathrm{~L}^{-1}, \mathrm{~K}_{2} \mathrm{HPO}_{4}: 0.5 \mathrm{~g} \mathrm{~L}^{-1}, \mathrm{FeSO}_{4}: 0.05 \mathrm{~g} \mathrm{~L}^{-1}$, $\mathrm{MnSO}_{4}: 0.01 \mathrm{~g} \mathrm{~L}^{-1}, \mathrm{MgSO}_{4}: 0.01 \mathrm{~g} \mathrm{~L}^{-1}, \mathrm{NaCl}: 0.02 \mathrm{~g} \mathrm{~L}^{-1}$, $\mathrm{CaCl}_{2}: 0.01 \mathrm{~g} \mathrm{~L}^{-1}, \mathrm{Na}_{2} \mathrm{MoO}_{4}: 0.002 \mathrm{~g} \mathrm{~L}^{-1}, \mathrm{pH} 6.8,1 \%$ Bromothymol blue solution). Nitrogen fixing microorganisms were identified by a color change from pale green to blue (Syed-Ab-Rahman et al., 2018; Kuan et al., 2016; Goswami et al., 2015). Phosphate solubilization and potassium solubilization were evaluated with commercial Pikovskaya agar medium and Aleksandrov agar medium, respectively. Media were added with $1 \%$ Bromothymol blue (BTB) solution to improve visualization of the clearing zones. $P$ and $K$ solubilizing microorganisms were identified by a color change from pale green to yellow and by the presence of clear halo zones around the colonies (Syed-Ab-Rahman et al., 2018; Kuan et al., 2016; Lima-Rivera et al., 2016; Rajawat et al., 2016; Sharon et al., 2016; Goswami et al., 2015; Zhang and Kong, 2014; Gupta et al., 2012). Plates were incubated at $30^{\circ} \mathrm{C}$ for 5 days for bacteria, and $20^{\circ} \mathrm{C}$ in darkness for 10 days for fungi.
Positive strains to each growth-promoting trait, with visual morphological differences, were sub-cultured by transferring them into the same agar medium to obtain pure colonies. Isolates were classified by the size of the clear halo zone measured from the edge of the colony. For $\mathrm{P}$ and $\mathrm{K}$ solubilization the halo zone was classified as level $1(1 \mathrm{~mm})$, level $2(2-4 \mathrm{~mm})$ and level $3(\geq 5 \mathrm{~mm})$. In the case of $\mathrm{N}$-fixation, $5 \mathrm{~mm}, 10-14 \mathrm{~mm}$ and $\geq 15$ $\mathrm{mm}$, for level 1, 2 and 3, respectively. Selected isolates (level 3) were transferred back to enriched media for storage at $4{ }^{\circ} \mathrm{C}$ and subsequent characterization.

Isolates were identified by MALDI-TOF mass spectrometry (MALDI-TOF MS). For this, selected bacterial isolates (level 3 of PGP trait) were sub-cultured to obtain clearly separated colonies in standard solid medium without nutrient limitation [tryptic soy agar (TSA)]. Spore-free fungal cultures were prepared in $25 \mathrm{~mL}$ PDB medium incubated in the dark for 7 days at $20^{\circ} \mathrm{C}$ and $130 \mathrm{rpm}$, cultures were washed three times with sterile distilled water. Bacterial samples were taken directly from TSA plates $\left(48 \mathrm{~h}, 30^{\circ} \mathrm{C}\right)$; plates were stored for 2 days at 4 ${ }^{\circ} \mathrm{C}$ until analysis. For fungal samples, a protein extract (ethanol/formic acid extraction) described by Bruker Daltonik (2011) from spore-free fungal cultures: PDB, 7 days, $20^{\circ} \mathrm{C}, 130 \mathrm{rpm}$, was prepared for identification. One $\mu \mathrm{L}$ of the microbial material was transferred to the MSP 96 polished steel BC target. The sample spot was air dried at room temperature and covered with $1 \mu \mathrm{l}$ of saturated $\alpha$-cyano-4-hydroxy-cinnamic acid (CHCA) matrix solution in $50 \%$ acetonitrile, $47.5 \%$ water, $2.5 \%$ trifluoroacetic acid. Each sample was analyzed by triplicate using a Microflex LT (Bruker Daltonics) MALDI-TOF mass spectrometer. Mass spectra were compared with reference mass spectra using the MALDI BIOTYPER 3.1 software with FILAMENTOUS FUNGI and BDAL databases. The software estimates a score value between 0 and 3 to determine the similarity between the sample and reference spectrum. Scores between 2.300 and 3.000 represented a high identification reliability at species level, whereas scores between 2.000 and 2.299 provided a high reliability of identification at the genus level (probable species identification), scores between 1.700 and 1.999 represented a probable genera identification and scores of 1.699 and below represented an unreliable identification (Schulthess et al., 2014; Bruker Daltonik, 2011).

From the identified microbial species, six fungal and nine bacterial species were used in this study. To verify 
that the isolates were axenic and that their microscopic characteristics corresponded to the indicated species, cultures were examined microscopically using Gram and lactophenol cotton blue stain for bacteria and fungi, respectively. Cell morphology was observed using a light microscope using a Leica EC4 Camara (Leica DM750, Germany). Plant growth promoting activity of each identified species was determined by reports in scientific literature.

\section{Fungal and bacterial inocula propagation}

Selected bacterial strains were individually grown in glass bottle flasks containing $250 \mathrm{~mL}$ of tryptic soy broth (TSB) and incubated on a rotary shaker at 180 rpm and $30^{\circ} \mathrm{C}$ for $72 \mathrm{~h}$. Bacterial growth was monitored spectroscopically until an optical density $(600 \mathrm{~nm})$ between 0.8 and 1 was reached, which corresponded to plate counts of $10^{7}-10^{8} \mathrm{CFU} \mathrm{mL}{ }^{-1}$. Bacterial growth was confirmed by plate count in TSA plates $\left(24 \mathrm{~h}, 30^{\circ} \mathrm{C}\right)$, dilutions in which bacteria formed between 30 and 300 colonies were considered to perform plate count.

For fungal inocula, potato dextrose agar (PDA) plates were inoculated and spores of 10-day old cultures were collected. For this, $5 \mathrm{~mL}$ of sterile distilled water were added to each plate and colonies were scraped to create a spore suspension. Spores were then transferred to a sterile $50 \mathrm{~mL}$ Falcon tube and adjusted to maximum volume with sterile distilled water. A Neubauer chamber was used to perform spore count.
Bacterial and fungal inocula were stored at $4{ }^{\circ} \mathrm{C}$ for a maximum of one week until biofertilizer formulation and application.

\section{Microbial consortia formulation}

To prepare the microbial consortia, a final concentration of $10^{7}-10^{8} \mathrm{CFU} \mathrm{mL} \mathrm{mL}^{-1}$ and $10^{6}$ spores $\mathrm{mL}^{-1}$ were used for bacteria and fungi, respectively. Inocula were mixed according to their growth promoting traits (nitrogen fixation (NF), phosphorus solubilization (PS), potassium solubilization (KS)), resulting in ten treatments (Table 1 ). It is also important to evaluate the effect on plants resulting from the type of interaction between fungi and bacteria. Controls were uninoculated plants. Equal volumes of each cell suspension were mixed according to the microbial consortia formulation.

\section{Experimental design and culture conditions}

Experiments were carried out as a completely randomized design in plastic seedbeds of 72 cavities $(5 \mathrm{~cm}$ in diameter, $5 \mathrm{~cm}$ depth), filled to $3 / 4$ of their capacity with commercial disinfected non-sterile black soil Nutrigarden $®$. Treatments were evaluated in maize (Zea mays) hybrid $\mathrm{H}-70$, each cavity was sown with two seeds at $0.5-1 \mathrm{~cm}$ deep, considering ten replicates per treatment. Seedlings were thinned down to one plant per plot after emergence. Inoculation was done at day 4,14 and 24 by applying $0.2 \mathrm{~mL}$ of the microbial consortia formulation to each cavity of each microbial

Table 1. Formulation of microbial consortia for seedbed testing

\begin{tabular}{ccc}
\hline Treatment ID & Description & Microbial consortia \\
\hline T1 & KS fungi & Penicillium consortia (H1, H10, H12, H13) \\
T2 & PS fungi & Penicillium consortia (H2, H14), Penicillium oxalicum (H15), Aspergillus sp. (H16) \\
T3 & NF fungi & Penicillium consortia (H5, H8), Fusarium sp. (H9) \\
T4 & KS bacteria & Pseudomonas consortia (B1, B2, B4, B8, B10, B15) \\
T5 & PS bacteria & Pseudomonas consortia (B6, B13, B14, B16) \\
T6 & NF bacteria & Pseudomonas consortia (B3, B11, B12), Serratia liquefaciens (B5), Bacillus sp. (B7) \\
T7 & All bacteria mixed & Pseudomonas consortia (B1-B4, B6, B8, B10- B16), Serratia liquefaciens (B5), Bacillus sp. (B7) \\
T8 & PS fungi + NF & Penicillium consortia (H2, H14), Penicillium oxalicum (H15), Aspergillus sp. (H16), Pseudomonas consortia (B3, \\
T9 & bS fungi + PS & B11, B12), Serratia liquefaciens (B5), Bacillus sp. (B7) \\
b10 & bacteria & Penicillium consortia (H1, H10, H12, H13), Pseudomonas consortia (B6, B13, B14, B16) \\
NF fungi + KS & bacteria & Penicillium consortia (H5, H8), Fusarium sp. (H9), Pseudomonas consortia (B1, B2, B4, B8, B10, B15) \\
Control & - & Uninoculated
\end{tabular}


treatment in the seedbed. The assay was done from March to May of 2020 in outdoors conditions with a natural light cycle and an average maximum and minimum temperature of $33^{\circ} \mathrm{C}$ and $12{ }^{\circ} \mathrm{C}$, respectively, during the experimental period. Plants were watered twice a day $(10 \mathrm{~mL})$ with tap water during the first three weeks of the experiment; later irrigation was reduced $50 \%$ for the next three weeks.

\section{Plant growth measurements}

Forty-five days after planting, plants were harvested. The effect of the inoculants was determined according to plant height (cm), plant fresh weight (g), root fresh weight (g) and total fresh weight (g). Plant height was evaluated two times (at the middle and end of the experimental period), from the soil surface to the highest point of the plant. Weight was recorded using a compact balance (AandD Weighing EK-600i), averaging three measurements to set the final value. Root weight was recorded after shaking the plant to remove all soil particles.

\section{Statistical analysis}

Data was analyzed using one-way analysis of variance (ANOVA) and the Tukey test to determine statistical significance of the treatments on plant development. Significance level was $P<0.05$. Normality was confirmed with Shapiro-Wilk Test. The Real Statistics Resource Pack for Microsoft Excel 365 was used to perform the analysis.

\section{RESULTS}

\section{Microbial selection and identification}

Bacterial and fungal species were tested for $\mathrm{N}_{2}$ fixation, and solubilization of phosphate and potassium using $\mathrm{N}$-free solid malate medium (Nfb), Pikovskaya agar medium and Aleksandrov agar medium, respectively. All media were added with $1 \%$ bromothymol blue solution to improve halo and colony visualization and resolution. Positive microorganisms for each PGP trait were sub-cultured in the same medium, where they were isolated and classified depending on the activity level of the trait. Level 1 to 3 corresponded to $1 \mathrm{~mm}, 2-4 \mathrm{~mm}$ and $\geq 5$ $\mathrm{mm}$, respectively. For bacteria from level 3,16 isolates with the largest halos were selected which contemplated six nitrogen fixers, four phosphate solubilizers and six potassium solubilizers. For fungi from level 3, 16 strains were selected, including five nitrogen fixers, six phosphate solubilizers and six potassium solubilizers.
Sixteen bacterial and 16 spore-free fungal cultures were identified by MALDI-TOF MS obtaining $81 \%$ identification efficiency. Fungal isolates generated lower identification scores than bacteria, most fungi scores were between 1.7 and 1.8 (probable genera), while bacteria were from 1.8 to 2.1 (genus-level, probable species). Score differences can be associated with database variation, bacterial databases have greater species diversity and are more studied and updated than fungal databases. Nine out of 16 (56.3\%) fungi samples were identified, including four genera and eight species. The Penicillium genus was the most predominant (Table 2). For bacteria, 15 out of 16 (93.75\%) samples were identified, including three genera and nine species. In this case, Pseudomonas was the most abundant genus. Because some identified species had scores below two, microscopic and macroscopic morphological characteristics were used to confirm their identification.

Morphological studies of microbial isolates

Microscopic characteristics of the isolates were studied using light microscopy and specific stains for bacteria and fungi (i.e., Gram stain and lactophenol cotton blue stain, respectively). Consequently, MALDI-TOF microbial identification was verified with these observations. Figure 1 shows microscopy images of the fungal strains. Fungal strains classified as Penicillium species coincided with typical morphological characteristics of this genus, a filamentous fungus with simple or branched conidiophores ending in phialides organized in a brush-like bunch (Figure 1 A-F) (Smith et al., 1990). Morphology of the other fungal strains was in accordance with the species identification, Fusarium sp. (Figure $1 \mathrm{G}$ ) presented oval microconidia (Rahjoo et al., 2008) and Aspergillus sp. (Figure $1 \mathrm{H}$ ) presented conidiophores that terminate in a characteristic conidial head with conidia in one-celled circular structures (Diba et al., 2007).

Figure 2 shows the different bacterial isolates under Gram stain. As observed, all strains were Gram negative (i.e., they stained with safranin acquiring a pink-red color) and showed a rod-shaped bacilli morphology. These characteristics are in agreement with the characteristics of Pseudomonas, Serratia and Bacillus; Bacillus appeared as an elongated straight rod-shaped bacilli, while Pseudomonas and Serratia seem much smaller and slightly curved (Lindsay and Von Holy, 1999; Joung and Côté, 2002). 
Table 2. MALDI-TOF mass spectrometric identification of fungal and bacterial isolates

\begin{tabular}{|c|c|c|c|c|}
\hline Isolate & Sample number & MALDI-TOF Result & MALDI-TOF score & Reliability \\
\hline \multirow{17}{*}{ Fungi } & $\mathrm{H} 1$ & Penicillium camemberti & 1.871 & Probable genus \\
\hline & $\mathrm{H} 2$ & Penicillium camemberti & 1.795 & Probable genus \\
\hline & $\mathrm{H} 3$ & Unidentified & - & \\
\hline & $\mathrm{H} 4$ & Unidentified & - & \\
\hline & H5 & Penicillium camemberti & 1.899 & Probable genus \\
\hline & $\mathrm{H} 6$ & Unidentified & - & \\
\hline & $\mathrm{H} 7$ & Unidentified & - & \\
\hline & $\mathrm{H} 8$ & Unidentified & - & \\
\hline & & & & \\
\hline & $\mathrm{H} 9$ & Fusarium oxysporum & 1.816 & Probable genus \\
\hline & $\mathrm{H} 10$ & Penicillium expansum & 1.817 & Probable genus \\
\hline & $\mathrm{H} 11$ & Unidentified & - & \\
\hline & $\mathrm{H} 12$ & Penicillium commune & 1.873 & Probable genus \\
\hline & $\mathrm{H} 13$ & Penicillium aurantiogriseum & 1.825 & Probable genus \\
\hline & $\mathrm{H} 14$ & Penicillium expansum & 2.036 & Genus-level, probable species \\
\hline & H15 & Penicillium oxalicum & 2.371 & Species-level \\
\hline & $\mathrm{H} 16$ & Possibly Aspergillus niger & 1.645 & - \\
\hline \multirow{16}{*}{ Bacteria } & B1 & Pseudomonas fragi & 2.01 & Genus-level, probable species \\
\hline & B2 & Pseudomonas libanensis & 2.108 & Genus-level, probable species \\
\hline & B3 & Pseudomonas brassicacearum & 1.862 & Probable genus \\
\hline & B4 & Pseudomonas libanensis & 1.948 & Probable genus \\
\hline & B5 & Serratia liquefaciens & 2.416 & Species-level \\
\hline & B6 & Pseudomonas libanensis & 1.976 & Probable genus \\
\hline & B7 & Bacillus altitudinis & 1.736 & Probable genus \\
\hline & B8 & Pseudomonas taetrolens & 1.89 & Probable genus \\
\hline & B9 & Unidentified & - & \\
\hline & B10 & Pseudomonas rhodesiae & 2.195 & Genus-level, probable species \\
\hline & B11 & Pseudomonas rhodesiae & 2.256 & Genus-level, probable species \\
\hline & B12 & Pseudomonas chlororaphis & 2.1 & Genus-level, probable species \\
\hline & B13 & Pseudomonas protegens & 2.002 & Genus-level, probable species \\
\hline & B14 & Pseudomonas fragi & 2.072 & Genus-level, probable species \\
\hline & B15 & Pseudomonas fragi & 2.01 & Genus-level, probable species \\
\hline & B16 & Pseudomonas fragi & 2.094 & Genus-level, probable species \\
\hline
\end{tabular}

Reliability score: 2.300 to 3.000 correspond to high reliability at the species level, 2.000 to 2.299 high reliability at the genus level and probable species identification, 1.700 to 1.999 probable identification at the genus level and $<1.699$ unreliable identification. 


\section{SCIENTIAFUNG $*$ RUM}
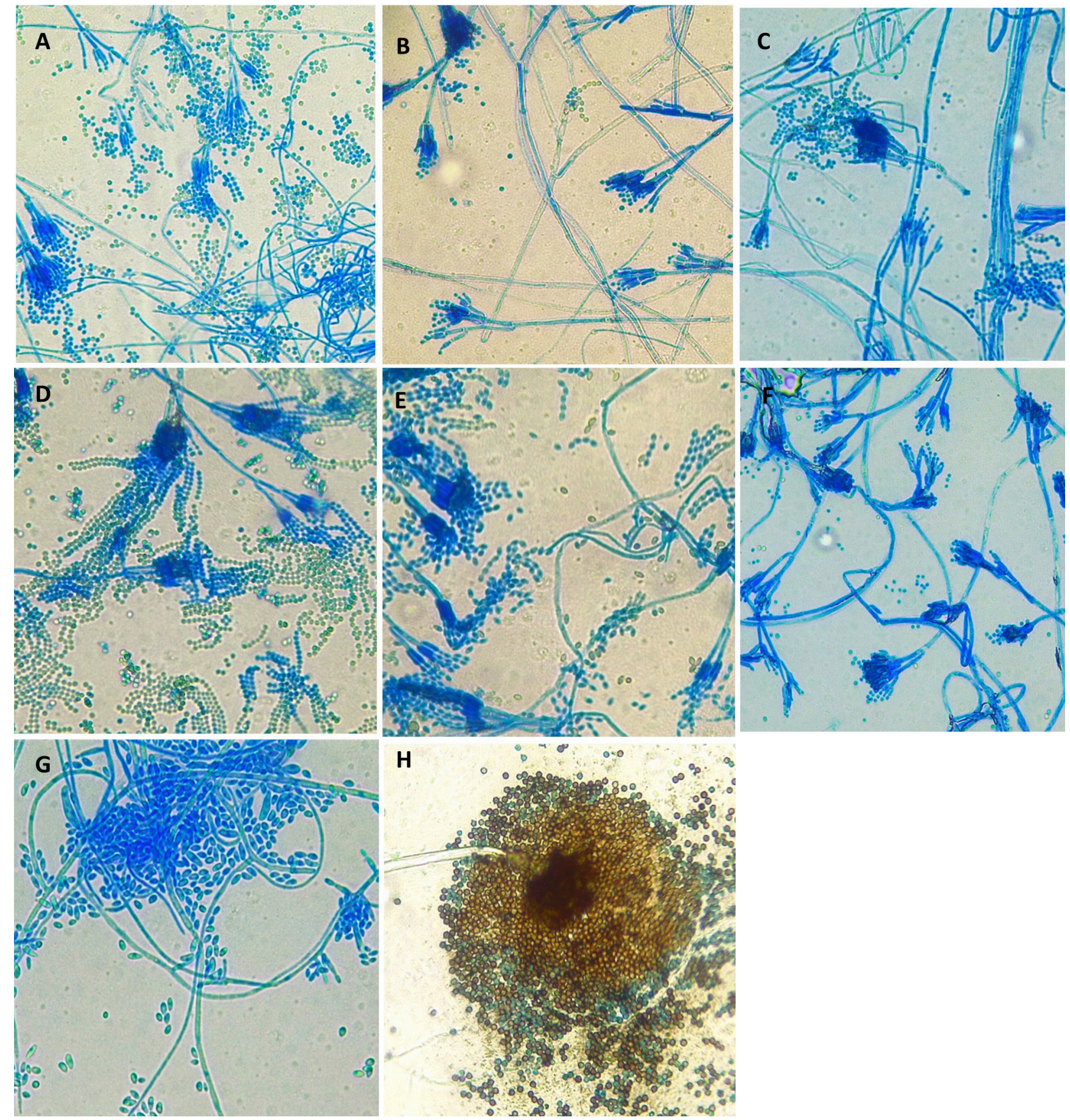

Figure 1. Microscopic images of lactophenol cotton blue-stained fungal isolates. A: Penicillium sp. (H5). B: Penicillium sp. (H14). C: Penicillium sp. (H12). D: Penicillium sp. (H13). E: Penicillium oxalicum (H15). F: Penicillium sp. (H3). G: Fusarium sp. (H9). H: Aspergillus sp. (H16). Magnification 1000x.

Early plant response to microbial consortia in a seedbed assay Ten microbial consortia were formulated and tested for initial plant response in maize. Forty-five days after planting, seedling growth parameters were assessed. Biofertilizer effect was measured according to maximum height, root and shoot fresh weight, and total fresh weight. Microbial consortia showed significant effects on maize growth compared to uninoculated plants, except for T2 whose effect was similar to the control in all parameters (Figure 3); also, plants grew healthy with no disease symptoms. Results showed that maximum height and shoot weight were signifi- 

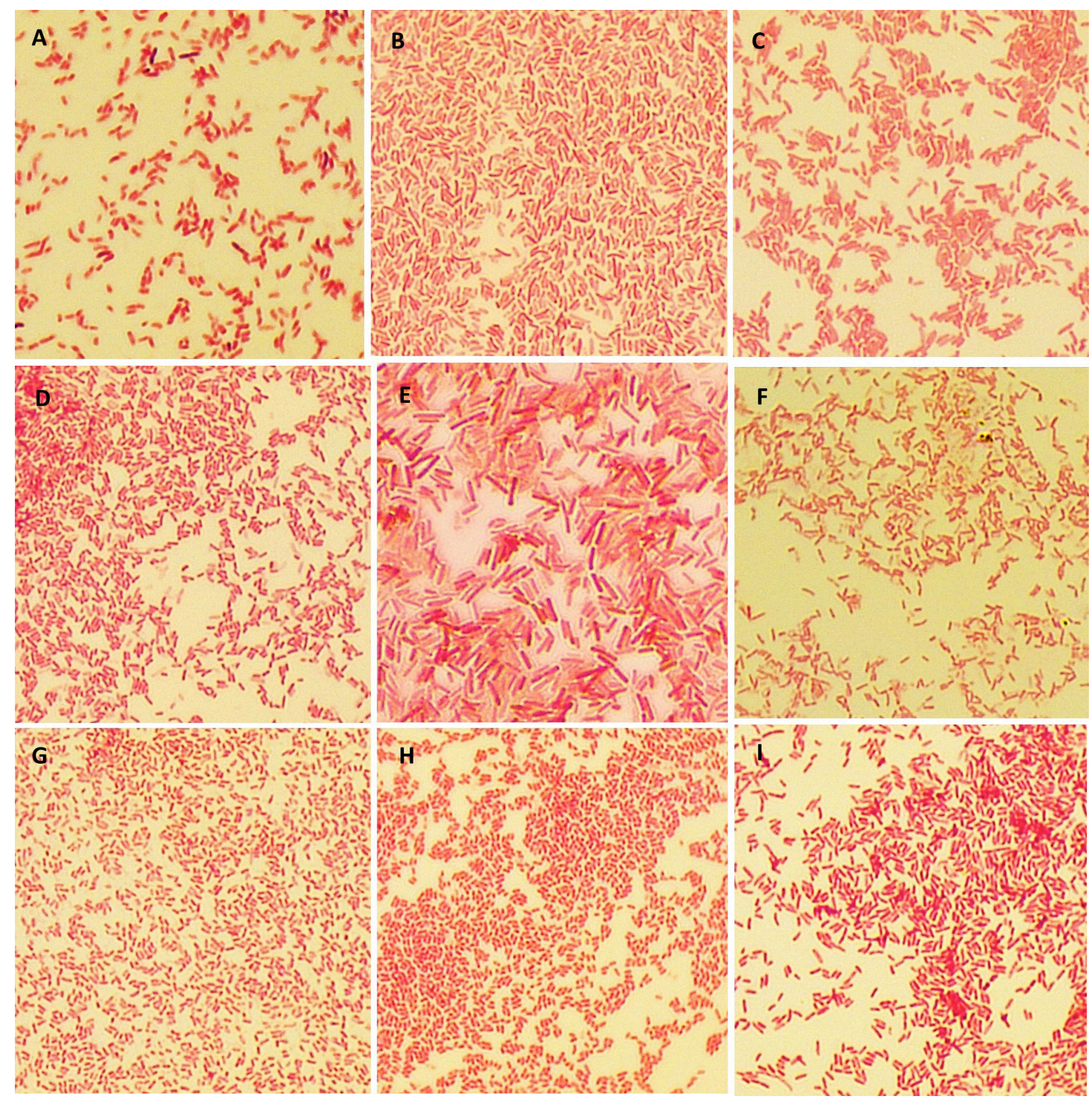

Figure 2. Microscopic images of Gram-stained bacterial isolates. A: Pseudomonas sp. (B1). B: Pseudomonas sp. (B4). C: Pseudomonas sp. (B3). D: Serratia liquefaciens (B5). E: Bacillus sp. (B7). F: Pseudomonas sp. (B8). G: Pseudomonas sp. (B11). H: Pseudomonas sp. (B12). I: Pseudomonas sp. (B13). Magnification 1000x.

cantly influenced mainly by bacterial consortia (T4 to T7). These treatments had an increase in plant height of 24 to $33 \%$ compared to the control, while only one fungal formulation (T3) had an effect on height, $30 \%$ higher than the control (Figure $3 \mathrm{~A}$ ). Shoot biomass was significantly improved by treatments $\mathrm{T4}, \mathrm{T} 5$ and $\mathrm{T} 7$ by 60-70 \% (Figure $3 \mathrm{C}$ ).
Regarding root weight, it was mainly influenced by the fungal formulation T3 and the combination of bacterial and fungal consortia (T8 to T10), achieving an increase in root weight between 71 and 85 \% (Figure 3 B). Figure 4 shows a comparison of plants under treatments $\mathrm{T3}$ (A), T5 (B), T8 (C) and T7 (D). They all showed similar shoot characteristics but evident differences in the root 

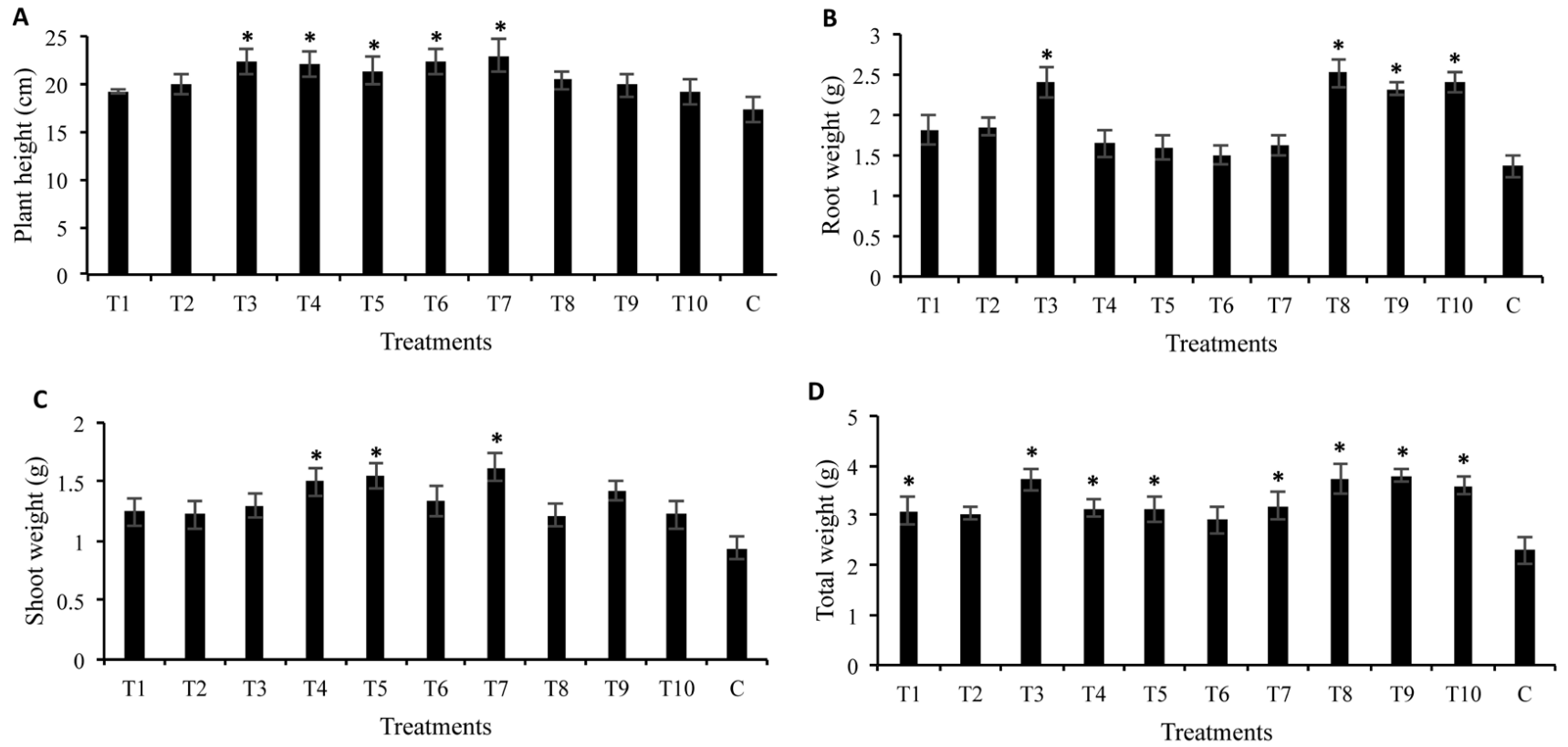

Figure 3. Microbial consortia effects on outdoor grown maize. A: Maximum height. B: Fresh root weight. C: Fresh shoot weight. D: Total fresh weight. * Significant difference from control $(P<0.05)$ using one-way analysis of variance and Tukey test $(n=100)$, data represent average of each parameter \pm standard error. T1: Penicillium consortia (H1, H10, H12, H13). T2: Penicillium consortia (H2, H14), Penicillium oxalicum (H15), Aspergillus sp. (H16). T3: Penicillium consortia (H5, H8), Fusarium sp. (H9). T4: Pseudomonas consortia (B1, B2, B4, B8, B10, B15). T5: Pseudomonas consortia (B6, B13, B14, B16). T6: Pseudomonas consortia (B3, B11, B12), Serratia liquefaciens (B5), Bacillus sp. (B7). T7: Pseudomonas consortia (B1-B4, B6, B8, B10- B16), Serratia liquefaciens (B5), Bacillus sp. (B7). T8: Penicillium consortia (H2, H14), Penicillium oxalicum (H15), Aspergillus sp. (H16), Pseudomonas consortia (B3, B11, B12), Serratia liquefaciens (B5), Bacillus sp. (B7). T9: Penicillium consortia (H1, H10, H12, H13), Pseudomonas consortia (B6, B13, B14, B16). T10: Penicillium consortia (H5, H8), Fusarium sp. (H9), Pseudomonas consortia (B1, B2, B4, B8, B10, B15). C: Uninoculated plants.
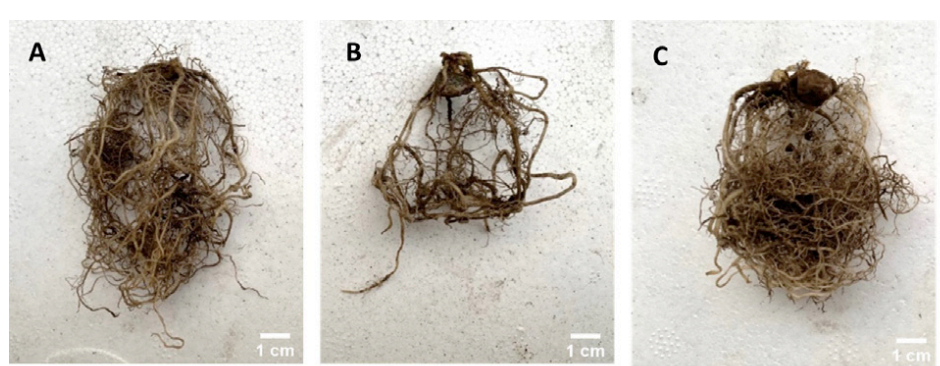

D

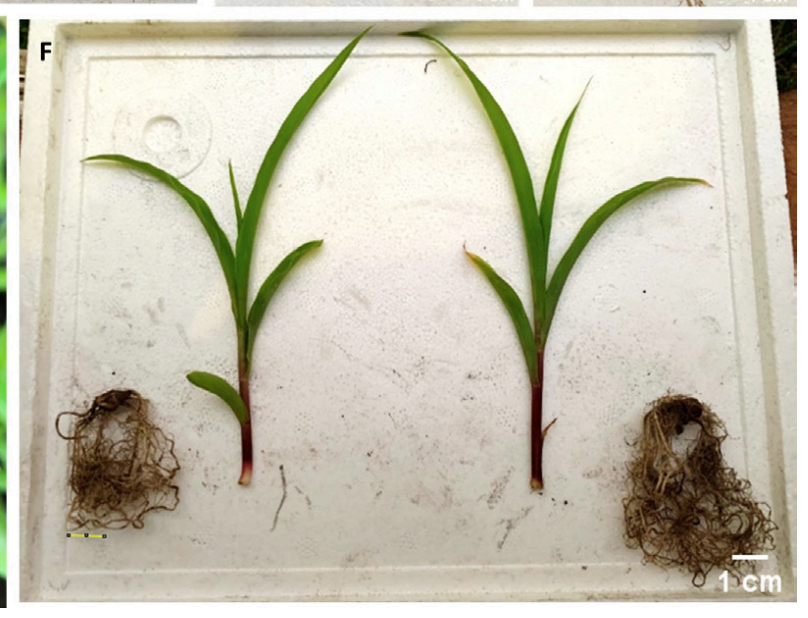

Figure 4. Maize growth measurements. A: Treatment 3, plant 2: maximum height $20.5 \mathrm{~cm}$, root weight $2.5 \mathrm{~g}$, shoot weight $1.2 \mathrm{~g}$. B: Treatment 5, plant 2: maximum height $22 \mathrm{~cm}$, root weight $1.3 \mathrm{~g}$, shoot weight $1.7 \mathrm{~g}$ (not significantly different from the control). C: Treatment 8 , plant 2: maximum height $20.5 \mathrm{~cm}$, root weight $2.4 \mathrm{~g}$, shoot weight $1.1 \mathrm{~g}$. D: Treatment 7, plant 2: maximum height $23.5 \mathrm{~cm}$, root weight $1.5 \mathrm{~g}$, shoot weight $1.7 \mathrm{~g}$ (not significantly different from the control). E: Fungal growth on roots. F: Comparison of plants from T5 (left) and T3 (right) with similar shoot growth, but significantly different root development. 
system, T3 and T8 had a significant $(P<0.05)$ increment in root biomass. Also, root branching and lateral root development were more predominant based on visual characteristics.

In general, the total plant weight was significantly improved $(P<0.05)$ by all treatments except T2 and T6, which obtained similar values to the control (Figure 3 D). The total weight of the significant treatments was between $35 \%$ and $65 \%$ higher than the control (uninoculated plants).

\section{DISCUSSION}

MALDI-TOF mass spectrometry has been used successfully to characterize bacteria and fungi from soil samples (Avanzi et al., 2017; Borowik et al., 2017; Al-Kaabi et al., 2018; Pandey et al., 2019; Nazir et al., 2020). In this research, comparable efficiencies and score values were obtained. MALDI-TOF MS technique is described as a rapid and reliable tool to identify and differentiate microorganisms at genera level (Avanzi et al., 2017; Al-Kaabi et al., 2018). This experiment was focused on two main genera, Penicillium and Pseudomonas. Penicillium genus was the most abundant fungal genus, it is universally distributed in most environments, distinguished by its activity as a decomposer of organic compounds (Park et al., 2019). This genus is composed of around 200 known species, some of them with important industrial applications (Altaf et al., 2018). Moreover, Pseudomonas was the most predominant bacterial genus. Globally distributed, Pseudomonas is one of the most studied genera for its multiple plant growth promoting traits (Preston, 2004; Santoyo et al., 2012; Radhapriya et al., 2015; Widnyana and Javandira, 2016; Dorjey et al., 2017).

In this study, formulations of different microbial consortia as potential biofertilizers showed that treatments that were most effective in promoting growth and shoot biomass (T4 to T7), consisted of bacteria mainly of the genus Pseudomonas. Bacterial strains from these consortia have been reported by several authors as having multifunctional plant growth-promoting attributes with significant beneficial effects on plant growth including enhanced nutrient uptake, production of indole-3-acetic acid (IAA), 1-aminocyclopropane-1-carboxylic acid (ACC) deaminase, siderophores and ammonia (Selvakumar et al., 2009; Adediran et al., 2015; Chen et al., 2015; Singh et al., 2015; Yadav et al., 2015; Fox et al., 2016;
Jain and Pandey, 2016; Ogata-Gutiérrez et al., 2016; Romero et al., 2016; Kamran et al., 2017; Kong et al., 2017; Etminani and Harighi, 2018; Andreolli et al., 2019; Kour et al., 2019). Plant height and shoot growth promotion are controlled by various factors, especially nutrition. In this sense, the experimental plants were grown on the same substrate without fertilization, differences in nutrient absorption may be attributed to the effect of microorganisms as they increase nutrient bioavailability from the substrate, mainly by phosphorus and potassium solubilization, and nitrogen fixation. The amount of available nutrients has a positive correlation with the increase in plant height, especially nitrogen since it is the most important nutrient for plant growth, essential for synthesis of amino acids that constitute proteins and chlorophyll for the process of photosynthesis (Richardson et al., 2009; Pirasteh and Li, 2017).

Also, plant growth regulators produced by microorganisms influence many physiological plant processes. Pseudomonas, Serratia and Bacillus strains used in this study are reported to produce the auxin IAA (Kang et al., 2006; Selvakumar et al., 2009; Yadav et al., 2015; Ogata-Gutiérrez et al., 2016; Romero et al., 2016; Kong et al., 2017; Kour et al., 2019), which is essential for plant growth, controlling leaf formation, vascular tissue differentiation, embryo development, cell elongation, microbial-plant interactions, branching, apical dominance, and also root initiation and development, including improvements in root length, root branching, root hairs and lateral root formation (Mohite, 2013; Dutta et al., 2015; Fahad et al., 2015; Chandra et al., 2018; Ojuederie et al., 2019). However, IAA levels may not be sufficient since bacterial consortia (T4 to T7) did not influence root weight, whereas shoot development could be influenced by the production of other phytohormones. Gibberellic acid (GA) is a terpenoid hormone that is directly involved in cell elongation of stems and germination (Sharma et al., 2018). Several authors reported GA production by different Pseudomonas species (Prabavathy et al., 2011; Ponmurugan et al., 2011; Qessaoui et al., 2019). Sharma et al. (2018) evaluated GA production in thirty Pseudomonas isolates, reaching production levels ranging from 116.1 - $485.8 \mathrm{mg} \mathrm{L}^{-1}$. Pandya et al. (2011) described that Pseudomonas species produce more GA than other PGPBs (Bacillus sp., Azotobacter sp. and Rhizobium sp.), achieving a maximum level of $290 \mathrm{mg} \mathrm{L}^{-1}$. 
Other authors have also shown positive effects of using Pseudomonas species in consortium with other bacterial species, describing synergistic activities to enhance plant growth. Pseudomonas putida and Bacillus amyloliquefaciens improved plant growth and drought stress tolerance in chickpea (Vurukonda et al., 2016; Kumar et al., 2016, Glick, 2014). Azotobacter chrocoocum and Pseudomonas sp. induced anatomical changes in the dermal and vascular tissue of wheat plants, improving growth and stress resistance (El-Afry et al., 2012). Pseudomonas fluorescens, P. jessenii, P. synxantha, B. cereus, and Arthrobacter nitroguajacolicus prevented oxidative stress in rice exposed to stress conditions (Gusain et al., 2015).

Regarding root development, the mixture of fungal and bacterial consortia (T8 to T10) significantly influenced root weight. In addition to the plant growth-promoting properties of bacterial species, fungal strains, mainly Penicillium and Aspergillus species, are recognized as potential plant growth promoters (Xiao et al., 2009; Gong et al., 2014; Ruangsanka, 2014; Panchala et al., 2015; Yin et al., 2015; Anand et al., 2016; Li et al., 2016; Malusá et al., 2016; Sahoo and Gupta, 2017; Banerjee and Dutta, 2019; Wang et al., 2020). On the other hand, some strains of Fusarium are recognized as plant pathogens, causing fusarium wilt and rot disease (Shanmugam and Kanoujia, 2011; Shanmugam et al., 2011; Shen et al., 2015; Xiong et al., 2017). However, it is also described that some non-pathogenic strains of Fusarium are able to promote plant growth, reduce nematode infections and increase arbuscular mycorrhizal fungi (AMF) colonization rates (Diedhiou et al., 2003). Therefore, it is suspected that the Fusarium sp. strain used in this study is a non-pathogenic strain since plants did not show disease symptoms and this microorganism was a component of one of the treatments with the best effects on shoot and root development (T3).

Mixing fungi and bacteria has been reported as an effective bioformulation to increase plant growth (Thakkar and Saraf, 2015; Schoebitz et al., 2016; Bilal et al., 2018). It has been hypothesized that the PGP traits of the microorganisms that make up a consortium exert an additive and complementary effect to enhance plant growth, thus the consortium effectiveness depends on the synergistic interaction of its components (Rashid et al., 2016). Fungi have larger and more resistant structures that bacteria and have the advantage of spreading and expanding more easily through the soil and the rhizosphere, increasing their effective area (Ortíz-Castro et al., 2009; Chandra et al., 2018). It is reported that fungi reach higher levels of phosphorus solubilization than bacteria; the solubilization levels of $A$. niger are around $468 \mathrm{mg} \mathrm{L}^{-1}$ soluble phosphate (Bhattacharya et al., 2015), while P. libanensis solubilizes only $199.10 \mathrm{mg} \mathrm{L}^{-1}$ (Kour et al., 2019). P-solubilizing activities are complemented by higher levels of IAA production in bacteria since the architecture of the root system is regulated by the auxin levels and nutrient availability, both trigger the initiation and development of lateral roots (Ortíz-Castro et al., 2009).

In arid environments, primary roots are not affected by drought conditions but growth of lateral roots is significantly limited, mostly by repression of the lateral root meristem. It is known that small lateral roots are important to increase the absorptive surface to resist environmental stress (Basu et al., 2016; Ngumbi and Kloepper, 2016; Fahad et al., 2017). Indirect and direct improvements to the architecture of the root system is an important factor to increase plant tolerance to drought. Although surface water evaporates easily, in deeper layers there is enough moisture to supply water to the plant. A strong and extensive root system is essential to increase water use efficiency and capacity of the plant to reach and absorb nutrients, which increases crop yields (Wasaya et al., 2018). Therefore, application of native soil microorganisms as consortia may deliver multifunctional growth-promoting traits to plants, which are essential to enhance crop growth, and could increase plant drought stress tolerance by improving the root system. Nevertheless, further research is required to describe the effect of these species when plants are exposed to drought stress or other harsh environmental conditions.

\section{CONCLUSIONS}

Fungal and bacterial strains were isolated from arid zones, characterized for plant growth promoting traits, identified by MALDI-TOF and propagated to generate ten microbial consortia that were evaluated in maize under seedbed conditions. Significant growth promotion effects were found at an early plant developmental stage in maize growth; consortia had significant improvements on shoot growth and root development. Bacterial consortia mainly promoted development of plant 
aerial biomass, while combination of fungal and bacterial species notably increased root biomass by the development of lateral roots and root hairs. Next steps of optimization of the evaluated microbial consortia will contemplate selection of species with the best performance and generate a highly effective biofertilizer composed of a microbial consortium that can be tested under greenhouse and field conditions.

\section{ACKNOWLEDGMENTS}

This study was funded by the Mexican-German bilateral scientific and technological cooperation project, by FONCICYT-CONACYT-National Council of Science and Technology of Mexico (grant no. 267782) and BMBF Germany (grant no. 01DN17031). Graduate academic scholarships for CEGM were provided by CONACYT and Tecnológico de Monterrey.

\section{REFERENCES}

Adediran, G.A., B.T. Ngwenya, J.F.W. Mosselmans, K. Heal, B.A. Harvie, 2015. Mechanisms behind bacteria induced plant growth promotion and $\mathrm{Zn}$ accumulation in Brassica juncea. Journal of Hazardous Materials 283: 490-499. Doi: 10.1016/j. jhazmat.2014.09.064

Adisa, I.O., V.L.R. Pullagurala, J.R. Peralta-Videa, C.O. Dimkpa, W.H. Elmer, J. Gardea-Torresdey, J. White, 2019. Recent advances in nano-enabled fertilizers and pesticides: A critical review of mechanisms of action. Environmental Science: Nano 6: 2002-2030. Doi: 10.1039/C9EN00265K

Aggani, S.L., 2013. Development of bio-fertilizers and its future perspective. Scholars Academic Journal of Pharmacy 2: 327-332.

Al-Kaabi, N., M.A. Al-Ghouti, M. Oualha, M.Y. Mohammad, A. Al-Naemi, T.I. Sølling, N. Zouari, 2018. A MALDI-TOF study of bio-remediation in highly weathered oil contaminated soils. Journal of Petroleum Science and Engineering 168: 569576. Doi: 10.1016/j.petrol.2018.05.013

Alori, E.T., B.R. Glick, O.O. Babalola, 2017. Microbial phosphorus solubilization and its potential for use in sustainable agriculture. Frontiers in Microbiology 8: 971. Doi: 10.3389/ fmicb.2017.00971

Altaf, M.M., M. Imran, H.H. Abulreesh, M.S. Khan, I. Ahmad, 2018. Diversity and applications of Penicillium spp. in plant-growth promotion. In: Gupta, V. K., S. Rodriguez-Couto (eds.), New and future developments in microbial biotechnology and bioengineering. Elsevier, Oxford. Pp. 261-276. Doi: 10.1016/B978-0444-63501-3.00015-6

Anand, K., B. Kumari, M.A. Mallick, 2016. Phosphate solubilizing microbes: an effective and alternative approach as biofertilizers. Journal of Pharmaceutical Sciences 8: 37-40.

Andreolli, M., G. Zapparoli, E. Angelini, G. Lucchetta, S. Lampis, G. Vallini, 2019. Pseudomonas protegens MP12: a plant growth-promoting endophytic bacterium with broad-spectrum antifungal activity against grapevine phytopathogens. Microbiological Research 219: 123-131. Doi: 10.1016/j.micres.2018.11.003
Avanzi, I.R., L.H. Gracioso, M.D.P.G. Baltazar, B. Karolski, E.A. Perpetuo, C.A.O. do Nascimento, 2017. Rapid bacteria identification from environmental mining samples using MALDI-TOF MS analysis. Environmental Science and Pollution Research 24: 3717-3726. Doi: 10.1007/s11356-016-8125-8

Banerjee, S., S. Dutta, 2019. Plant growth promoting activities of a fungal strain Penicillium commune MCC 1720 and its effect on growth of black gram. Pharma Innovation Journal 8: 121-127.

Bardi L, E. Malusà, 2012. Drought and nutritional stresses in plant: alleviating role of rhizospheric microorganisms. In: Haryana N., S. Punj (eds.), Abiotic stress: New research. Nova Science Publishers Inc., Hauppauge. Pp. 1-57.

Basu, S., V. Ramegowda, A. Kumar, A. Pereira, 2016. Plant adaptation to drought stress. F1000Research: 5 (F1000 Faculty Rev):1554. Doi: 10.12688/f1000research.7678.1

Berruti, A., E. Lumini, R. Balestrini, V. Bianciotto, 2016. Arbuscular mycorrhizal fungi as natural biofertilizers: let's benefit from past successes. Frontiers in microbiology 6: 1559. Doi: 10.3389/ fmicb.2015.01559

Bhardwaj D, M.W. Ansari, R.K. Sahoo, N. Tuteja, 2014. Biofertilizers function as key player in sustainable agriculture by improving soil fertility, plant tolerance and crop productivity. Microbial Cell Factories 13: 66. Doi: 10.1186/1475-2859-13-66

Bhattacharya, S., A. Das, S. Bhardwaj, S.S. Rajan, 2015. Phosphate solubilizing potential of Aspergillus niger MPF-8 isolated from Muthupettai mangrove. Journal of Scientific and Industrial Research 74: 499-503.

Bilal, S., R. Shahzad, A.L. Khan, S.M. Kang, Q.M. Imran, A. Al-Harrasi, B.W. Yun, I.J. Lee, 2018. Endophytic microbial consortia of phytohormones-producing fungus Paecilomyces formosus LHL10 and bacteria Sphingomonas sp. LK11 to Glycine max L. regulates physio-hormonal changes to attenuate aluminum and zinc stresses. Frontiers in Plant Science 9: 1273. Doi: 10.3389/ fpls.2018.01273

Borowik, A., J. Wyszkowska, K. Oszust, 2017. Functional diversity of fungal communities in soil contaminated with diesel oil. Frontiers in Microbiology 8: 1862. Doi: 10.3389/fmicb.2017.01862

Bruker Daltonik, 2011. Instructions for Use MALDI Biotarget 48. Retrieved from https://www.bruker.com/fileadmin/user_upload/8-PDF-Docs/Separations_MassSpectrometry/InstructionForUse/IFU_268711_267615_226413_MALDI_Biotarget_48_Rev1.pdf

Busby, P.E., C. Soman, M.R. Wagner, M.L. Friesen, J. Kremer, A. Bennett, M. Morsy, J. Eisen, J. Leach, J.L. Dangl, 2017. Research priorities for harnessing plant microbiomes in sustainable agriculture. PLoS Biology 15: e2001793. Doi: 10.1371/journal. pbio. 2001793

Carrington, D., 2018. Paul Ehrlich: 'Collapse of civilisation is a near certainty within decades'. Retrieved from https://www.theguardian.com/cities/2018/mar/22/collapse-civilisation-near-certain-decades-population-bomb-paul-ehrlich

Chandra, S., K. Askari, M. Kumari, 2018. Optimization of indole acetic acid production by isolated bacteria from Stevia rebaudiana rhizosphere and its effects on plant growth. Journal of Genetic Engineering and Biotechnology 16: 581-586. Doi: 10.1016/j. jgeb.2018.09.001 
Chen, Y., X, Shen, H. Peng, H. Hu, W. Wang, X. Zhang, 2015. Comparative genomic analysis and phenazine production of Pseudomonas chlororaphis, a plant growth-promoting Rhizobacterium. Genomics Data 4: 33-42. Doi: 10.1016/j.gdata.2015.01.006

DeLonge, M.S., A. Miles, L. Carlisle, 2016. Investing in the transition to sustainable agriculture. Environmental Science and Policy 55: 266-273. Doi: 10.1016/j.envsci.2015.09.013

Diba, K., P. Kordbacheh, S.H. Mirhendi, S. Rezaie, M. Mahmoudi, 2007. Identification of Aspergillus species using morphological characteristics. Pakistan Journal of Medical Sciences 23: 867.

Diedhiou, P.M., J. Hallmann, E.C. Oerke, H.W. Dehne, 2003. Effects of arbuscular mycorrhizal fungi and a non-pathogenic Fusarium oxysporum on Meloidogyne incognita infestation of tomato. Mycorrhiza 13: 199-204. Doi: 10.1007/s00572-002-0215-4

Dorjey, S., D. Dolkar, R. Sharma, 2017. Plant growth promoting rhizobacteria Pseudomonas: a review. International Journal of Current Microbiology and Applied Sciences 6: 1335-1344. Doi: 10.20546/ijcmas.2017.607.160

Drechsel, P., P. Heffer, H. Magen, R. Mikkelsen, D. Wichelns (eds.), 2015. Managing water and fertilizer for sustainable agricultural intensification. International Fertilizer Industry Association (IFA), International Water Management Institute (IWMI), International Plant Nutrition Institute (IPNI), and International Potash Institute (IPI), Paris.

Dutta, J., P.J. Handique, D. Thakur, 2015. Assessment of culturable tea rhizobacteria isolated from tea estates of Assam, India for growth promotion in commercial tea cultivars. Frontiers in Microbiology 6: 1252. Doi: 10.3389/fmicb.2015.01252

El-Afry, M.M., M.F. El-Nady, E.B. Abdelmonteleb, M.M.S. Metwaly, 2012. Anatomical studies on drought-stressed wheat plants (Triticum aestivum L.) treated with some bacterial strains. Acta Biologica Szegediensis 56: 165-174. http://www.sci.u-szeged.hu/ABS

ELD, 2015. Report for policy and decision makers: Reaping economic and environmental benefits from sustainable land management. Retrieved from www.eld-initiative.org.

Elemike, E.E., I.M. Uzoh, D.C. Onwudiwe, O.O. Babalola, 2019. The role of nanotechnology in the fortification of plant nutrients and improvement of crop production. Applied Sciences 9: 499. Doi: 10.3390/app9030499

El-Ghamry, A., A.A. Mosa, T. Alshaal, H. El-Ramady, 2018. Nanofertilizers vs. biofertilizers: new insights. Environment, Biodiversity and Soil Security 2: 51-72. Doi: 10.21608/jenvbs.2018.3880.1029

Emam, T., 2016. Local soil, but not commercial AMF inoculum, increases native and non-native grass growth at a mine restoration site. Restoration Ecology 24: 35-44. Doi: 10.1111/rec.12287

Etminani, F., B. Harighi, 2018. Isolation and identification of endophytic bacteria with plant growth promoting activity and biocontrol potential from wild pistachio trees. The Plant Pathology Journal 34: 208. Doi: 10.5423/PPJ.OA.07.2017.0158

Fahad, S., A.A. Bajwa, U. Nazir, S.A. Anjum, A. Farooq, A. Zohaib, S. Sadia, W. Nasim, S. Adkins, S. Saud, M. Ihsan, H. Alharby, C. Wu, D. Wang, J. Huang, 2017. Crop production under drought and heat stress: plant responses and management options. Frontiers in Plant Science 8: 1147. Doi: 10.3389/fpls.2017.01147

Fahad, S., S. Hussain, A. Bano, S. Saud, S. Hassan, S.D. Shan, F. Ahmed, F. Khan, Y. Chen, C. Wu, M.A. Tabassum, M.A. Chun, M.
Afzal, A. Jan, M.T. Jan, J. Huang, 2015. Potential role of phytohormones and plant growth-promoting rhizobacteria in abiotic stresses: consequences for changing environment. Environmental Science and Pollution Research 22: 4907-4921. Doi: 10.1007/ s11356-014-3754-2

FAO, 2009. La agricultura mundial en la perspectiva del año 2050. Retrieved from http://www.fao.org/fileadmin/templates/wsfs/docs/ Issues_papers/Issues_papers_SP/La_agricultura_mundial.pdf

FAO, 2015. Soil degradation: a major threat to humanity. Retrieved from http://www.fao.org/fsnforum/sites/default/files/discussions/contributions/Soil-degradation-Final-final_0.pdf

FAO, 2019. World fertilizer trends and outlook to 2022. Retrieved from http://www.fao.org/3/ca6746en/CA6746EN.pdf

Fox, A.R., G. Soto, C. Valverde, D. Russo, Jr. A. Lagares, A. Zorreguieta, K. Alleva, C. Pascuan, R. Frare, J. Mercado-Blanco, R. Dixon, N.D. Ayub, 2016. Major cereal crops benefit from biological nitrogen fixation when inoculated with the nitrogen-fixing bacterium Pseudomonas protegens Pf-5 X940. Environmental Microbiology 18: 3522-3534. Doi: 10.1111/1462-2920.13376

Glick, B.R., 2014. Bacteria with ACC deaminase can promote plant growth and help to feed the world. Microbiological Research 169: 30-39. Doi: 10.1016/j.micres.2013.09.009

Gong, M., P. Du, X. Liu, C. Zhu, 2014. Transformation of inorganic P fractions of soil and plant growth promotion by phosphate-solubilizing ability of Penicillium oxalicum I1. Journal of Microbiology 52: 1012-1019. Doi: 10.1007/s12275-014-4406-4

Goswami, D., S. Parmar, H. Vaghela, P. Dhandhukia, J.N. Thakker, 2015. Describing Paenibacillus mucilaginosus strain N3 as an efficient plant growth promoting rhizobacteria (PGPR). Cogent Food \& Agriculture 1: 1000714. Doi: 10.1080/23311932.2014.1000714

Gouda, S., R.G. Kerry, G. Das, S. Paramithiotis, H.S. Shin, J.K. Patra, 2018. Revitalization of plant growth promoting rhizobacteria for sustainable development in agriculture. Microbiological Research 206: 131-140. Doi: 10.1016/j.micres.2017.08.016

Guardiola-Márquez, C.E., A. Pacheco, C. Senés-Guerrero, 2019. Evaluación de biofertilizantes a base de microorganismos y lixiviado de vermicomposta en cultivos de interés económico en México. AGROProductividad 12: 53-62. Doi: 10.32854/agrop.v0i0.1348

Gupta, G., S.S. Parihar, N.K. Ahirwar, S.K. Snehi, V. Singh, 2015. Plant growth promoting rhizobacteria (PGPR): current and future prospects for development of sustainable agriculture. Journal of Microbial and Biochemical Technology 7: 96-102. Doi: 10.4172/1948-5948.1000188

Gusain, Y.S., U.S. Singh, A.K. Sharma, 2015. Bacterial mediated amelioration of drought stress in drought tolerant and susceptible cultivars of rice (Oryza sativa L.). African Journal of Biotechnology 14: 764-773. Doi: 10.5897/AJB2015.14405

Horrigan, L., R.S. Lawrence, P. Walker, 2002. How sustainable agriculture can address the environmental and human health harms of industrial agriculture. Environmental Health Perspectives 110: 445. Doi: 10.1289/ehp.02110445

INEGI, 2018. Información por entidad-Chihuahua. Retrieved from http://cuentame.inegi.org.mx/monografias/informacion/chih/ territorio/clima. aspx?tema $=$ me\&e $=08$

IPBES, 2018. Media Release: Worsening Worldwide Land Degradation Now 'Critical', Undermining Well-Being of 3.2 Billion People. 
Retrieved from https://ipbes.net/news/media-release-worsening-worldwide-land-degradation-now-\%E2\%80\%98critical\%E2\%80\%99-undermining-well-being-32

Isfahani, F.M., H. Besharati, 2012. Effect of biofertilizers on yield and yield components of cucumber. Journal of Biology and Earth Sciences 2: B83-92.

Jain, R., A. Pandey, 2016. A phenazine-1-carboxylic acid producing polyextremophilic Pseudomonas chlororaphis (MCC2693) strain, isolated from mountain ecosystem, possesses biocontrol and plant growth promotion abilities. Microbiological Research 190: 63-71. Doi: 10.1016/j.micres.2016.04.017

Jochum, M., K.M. McWilliams, E. Borrego, M. Kolomiets, G. Niu, E. Pierson, Y.K. Jo, 2019. Bioprospecting plant growth-promoting rhizobacteria that mitigate drought stress in grasses. Frontiers in Microbiology 10: 2106. Doi: 10.3389/fmicb.2019.02106

Joung, K.B., J.C. Côté, 2002. A single phylogenetic analysis of Bacillus thuringiensis strains and bacilli species inferred from $16 \mathrm{~S}$ rRNA gene restriction fragment length polymorphism is congruent with two independent phylogenetic analyses. Journal of Applied Microbiology 93: 1075-1082. Doi: 10.1046/j.13652672.2002.01788.x

Kamran, S., I. Shahid, D.N. Baig, M. Rizwan, K.A. Malik, S. Mehnaz, 2017. Contribution of zinc solubilizing bacteria in growth promotion and zinc content of wheat. Frontiers in Microbiology 8: 2593. Doi: $10.3389 / \mathrm{fmicb} .2017 .02593$

Kang, B.R., K.Y. Yang, B.H. Cho, T.H. Han, I.S. Kim, M.C. Lee, A.J. Anderson, Y.C. Kim, 2006. Production of indole-3-acetic acid in the plant-beneficial strain Pseudomonas chlororaphis $\mathrm{O} 6$ is negatively regulated by the global sensor kinase GacS. Current Microbiology 52: 473-476. Doi: 10.1007/s00284-005-0427-x

Kong, Z., Z. Deng, B.R. Glick, G. Wei, M. Chou, 2017. A nodule endophytic plant growth-promoting Pseudomonas and its effects on growth, nodulation and metal uptake in Medicago lupulina under copper stress. Annals of Microbiology 67: 49-58. Doi: 10.1007/s13213-016-1235-1

Kopittke, P.M., N.W. Menzies, P. Wang, B.A. McKenna, E. Lombi, 2019. Soil and the intensification of agriculture for global food security. Environment International 132: 105078. Doi: 10.1016/j. envint.2019.105078

Kour, D., K.L. Rana, I. Sheikh, V. Kumar, A.N. Yadav, H.S. Dhaliwal, A.K. Saxena, 2019. Alleviation of drought stress and plant growth promotion by Pseudomonas libanensis EU-LWNA-33, a drought-adaptive phosphorus-solubilizing bacterium. Proceedings of the National Academy of Sciences, India Section B: Biological Sciences 90: 785-795. Doi: 10.1007/s40011-01901151-4

Kuan, K.B., R. Othman, K.A. Rahim, Z.H. Shamsuddin, 2016. Plant growth-promoting rhizobacteria inoculation to enhance vegetative growth, nitrogen fixation and nitrogen remobilisation of maize under greenhouse conditions. PloS One 11: e0152478. Doi: 10.1371/journal.pone.0152478

Kumar, M., S. Mishra, V. Dixit, M. Kumar, L. Agarwal, P.S. Chauhan, C.S. Nautiyal, 2016. Synergistic effect of Pseudomonas putida and Bacillus amyloliquefaciens ameliorates drought stress in chickpea (Cicer arietinum L.). Plant Signaling and Behavior 11: e1071004. Doi: 10.1080/15592324.2015.1071004
Kumar, S., P. Pandey, D.K. Maheshwari, 2009. Reduction in dose of chemical fertilizers and growth enhancement of sesame (Sesamum indicum L.) with application of rhizospheric competent Pseudomonas aeruginosa LES4. European Journal of Soil Biology 45: 334-340. Doi: 10.1016/j.ejsobi.2009.04.002

Kumari, R., D.P. Singh, 2019. Nano-biofertilizer: an emerging eco-friendly approach for sustainable agriculture. Proceedings of the National Academy of Sciences, India Section B: Biological Sciences 90: 733-741. Doi: 10.1007/s40011-019-01133-6

Leahy, S., 2018. 75 \% of earth's land areas are degraded. Retrieved from https://www.nationalgeographic.com/news/2018/03/ipbes-land-degradation-environmental-damage-report-spd/

Li, Z., T. Bai, L. Dai, F. Wang, J. Tao, S. Meng, S. Hu, 2016. A study of organic acid production in contrasts between two phosphate solubilizing fungi: Penicillium oxalicum and Aspergillus niger. Scientific Reports 6: 1-8. Doi: 10.1038/srep25313

Lima-Rivera, D.L., D. Lopez-Lima, D. Desgarennes, A.S. Velazquez-Rodriguez, G. Carrion, 2016. Phosphate solubilization by fungi with nematicidal potential. Journal of Soil Science and Plant Nutrition 16: 507-524. Doi: 10.4067/S0718-95162016005000042

Lindsay, D., A. Von Holy, 1999. Different responses of planktonic and attached Bacillus subtilis and Pseudomonas fluorescens to sanitizer treatment. Journal of Food Protection 62: 368-379. Doi: 10.4315/0362-028x-62.4.368

Mahanty, T., S. Bhattacharjee, M. Goswami, P. Bhattacharyya, B. Das, A. Ghosh, P. Tribedi, 2017. Biofertilizers: a potential approach for sustainable agriculture development. Environmental Science and Pollution Research 24: 3315-3335. Doi: 10.1007/s11356016-8104-0

Malusá E., N. Vassilev, 2014. A contribution to set a legal framework for biofertilisers. Applied Microbiology and Biotechnology 98: 6599-6607. Doi: 10.1007/s00253-014-5828-y

Malusá, E., F. Pinzari, L. Canfora, 2016. Efficacy of biofertilizers: challenges to improve crop production. In: Singh, D., H. Singh, R. Prabha (eds.), Microbial inoculants in sustainable agricultural productivity. Springer, New Delhi. Pp. 17-40. Doi: 10.1007/97881-322-2644-4_2

Malusá, E., L. Sas-Paszt, J. Ciesielska, 2012. Technologies for beneficial microorganisms inocula used as biofertilizers. The Scientific World Journal Vol. 2012: 491206. Doi: 10.1100/2012/491206

Mohite, B., 2013. Isolation and characterization of indole acetic acid (IAA) producing bacteria from rhizospheric soil and its effect on plant growth. Journal of Soil Science and Plant Nutrition 13: 638649. Doi: 10.4067/S0718-95162013005000051

Naseem, H., A. Bano, 2014. Role of plant growth-promoting rhizobacteria and their exopolysaccharide in drought tolerance of maize.Journal of Plant Interactions 9: 689-701. Doi: 10.1080/17429145.2014.902125

Nazir, R., B.A. Ganai, P. Rahi, S. Rehman, S. Farooq, R. Dar, ... E.F. Abd_Allah, 2020. MALDI-TOF-MS and 16S rRNA characterization of lead tolerant metallophile bacteria isolated from saffron soils of Kashmir for their sequestration potential. Saudi Journal of Biological Sciences 27: 2047-2053. Doi: 10.1016/j.sjbs.2020.04.021

Ngumbi, E., J. Kloepper, 2016. Bacterial-mediated drought tolerance: current and future prospects. Applied Soil Ecology 105: 109-125. Doi: 10.1016/j.apsoil.2016.04.009 
Nurbaity, A., E.T. Sofyan, J.S. Hamdani, 2016. Application of Glomus sp. and Pseudomonas diminuta reduce the use of chemical fertilizers in production of potato grown on different soil types. In: IOP Conference Series: Earth and Environmental Science 41: 012004. Doi: 10.1088/1755-1315/41/1/012004

Ogata-Gutiérrez, K., D. Alvarado, C. Chumpitaz-Segovia, D. Zúñiga-Dávila, 2016. Characterization of plant growth promoting rhizobacteria isolated from the rhizosphere of Peruvian highlands native crops. International Journal of Plant and Soil Science 11: 1-8. Doi: $10.9734 /$ IJPSS/2016/24573

Ojuederie, O.B., O.S. Olanrewaju, O.O. Babalola, 2019. Plant growth promoting rhizobacterial mitigation of drought stress in crop plants: implications for sustainable agriculture. Agronomy 9: 712. Doi: 10.3390/agronomy9110712

Ortíz-Castro, R., H.A. Contreras-Cornejo, L. Macías-Rodríguez, J. López-Bucio, 2009. The role of microbial signals in plant growth and development. Plant Signaling and Behavior 4: 701-712. Doi: 10.4161/psb.4.8.9047

Panchala, B.J., S. Patela, S.J. Rajkumard, L. Mahatmac, D. Singha, 2015. Isolation and identification of phosphate solubilizing Penicillium expansum NAUG-B1 and their consequence on growth of brinjal. Ecology, Environment and Conservation 21: S259-S267.

Pandey, A., R. Jain, A. Sharma, K. Dhakar, G.S. Kaira, P. Rahi, ... Y.S. Shouche, 2019. 16S rRNA gene sequencing and MALDI-TOF mass spectrometry based comparative assessment and bioprospection of psychrotolerant bacteria isolated from high altitudes under mountain ecosystem. SN Applied Sciences 1: 278. Doi: 10.1007/s42452-019-0273-2

Pandya, N. D., N. V. Butani, P. V. Desai, R. Z. Sayyed, 2011. Optimization of $\mathrm{GA} 3$ biosynthesis by bacteria associated with the rhizosphere of sugarcane. In: Reddy, M.S., Q. Wang, Y. Li, L. Zhang, B. Du, S.K. Yellareddygari (eds.), Plant growth-promoting rhizobacteria (PGPR) for sustainable agriculture. Proceedings of the $2^{\text {nd }}$ Asian PGPR Conference, Beijing. p.447.

Park, M.S., S.Y. Oh, J.J. Fong, J. Houbraken, Y.W. Lim, 2019. The diversity and ecological roles of Penicillium in intertidal zones. Scientific Reports 9: 1-11. Doi: 10.1038/s41598-019-49966-5

Pirasteh, S., J. Li (eds.), 2017. Global changes and natural disaster management: geo-information technologies. Springer, Berlin. Doi: 10.1007/978-3-319-51844-2

Ponmurugan, P., K. Manjukarunambika, M.S. Reddy, 2011. In vitro studies on efficacy of Pseudomonas spp. for plant growth promoting traits and biocontrol of diseases in tea plants. In: Reddy, M.S., Q. Wang, Y. Li, L. Zhang, B. Du, S.K. Yellareddygari (eds.), Plant growth-promoting rhizobacteria (PGPR) for sustainable agriculture. Proceedings of the $2^{\text {nd }}$ Asian PGPR Conference, Beijing. p.116.

Prabavathy, V. R., S. Jegan, J. Ananthi, N. Sudha, 2011. Genetic diversity of PGPR Pseudomonas associated with rhizosphere of different crops cultivated in the saline agri-ecosystem. In: Reddy, M.S., Q. Wang, Y. Li, L. Zhang, B. Du, S.K. Yellareddygari (eds.), Plant growth-promoting rhizobacteria (PGPR) for sustainable agriculture. Proceedings of the $2^{\text {nd }}$ Asian PGPR Conference, Beijing. Pp.112-118.

Prasad, R., A. Bhattacharyya, Q.D. Nguyen, 2017. Nanotechnology in sustainable agriculture: recent developments, challenges, and perspectives. Frontiers in Microbiology 8: 1014. Doi: 10.3389/ fmicb.2017.01014

Preston, G.M., 2004. Plant perceptions of plant growth-promoting Pseudomonas. Philosophical Transactions of the Royal Society of London. Series B: Biological Sciences 359: 907-918. Doi: 10.1098/rstb.2003.1384

Qessaoui, R., R. Bouharroud, J.N. Furze, M. El Aalaoui, H. Akroud, A. Amarraque, J.V. Vaerenbergh R. Thazima, B. Chebli, 2019. Applications of new rhizobacteria Pseudomonas isolates in agroecology via fundamental processes complementing plant growth. Scientific Reports 9: 1-10. Doi: 10.1038/s41598-019-49216-8

Radhapriya, P., A. Ramachandran, R. Anandham, S. Mahalingam, 2015. Pseudomonas aeruginosa RRALC3 enhances the biomass, nutrient and carbon contents of Pongamia pinnata seedlings in degraded forest soil. PLoS One 10: e0139881. Doi: 10.1371/ journal.pone.0139881

Rahjoo, V., J. Zad, M. Javan-Nikkhah, A.M. Gohari, S.M. Okhovvat, M.R. Bihamta, M. R., Razzaghian, S.S. Klemsdal, 2008. Morphological and molecular identification of Fusarium isolated from maize ears in Iran. Journal of Plant Pathology 90: 463-468.

Rajawat, M.V.S., S. Singh, S.P. Tyagi, A.K. Saxena, 2016. A modified plate assay for rapid screening of potassium-solubilizing bacteria. Pedosphere 26: 768-773. Doi: 10.1016/S10020160(15)60080-7

Rashid, M.I., L.H. Mujawar, T. Shahzad, T. Almeelbi, I.M. Ismail, M. Oves, 2016. Bacteria and fungi can contribute to nutrients bioavailability and aggregate formation in degraded soils. Microbiological Research 183: 26-41. Doi: 10.1016/j.micres.2015.11.007

Richardson, A.E., J.M. Barea, A.M. McNeill, C. Prigent-Combaret, 2009. Acquisition of phosphorus and nitrogen in the rhizosphere and plant growth promotion by microorganisms. Plant and Soil 321: 305-339. Doi: 10.1007/s11104-009-9895-2

Roesti, D., R. Gaur, B.N. Johri, G. Imfeld, S. Sharma, K. Kawaljeet, M. Aragno, 2006. Plant growth stage, fertilizer management and bio-inoculation of arbuscular mycorrhizal fungi and plant growth promoting rhizobacteria affect the rhizobacterial community structure in rain-fed wheat fields. Soil Biology and Biochemistry 38: 1111-1120. Doi: 10.1016/j.soilbio.2005.09.010

Romero, F.M., M. Marina, F.L. Pieckenstain, 2016. Novel components of leaf bacterial communities of field-grown tomato plants and their potential for plant growth promotion and biocontrol of tomato diseases. Research in Microbiology 167: 222-233. Doi: 10.1016/j.resmic.2015.11.001

Ruangsanka, S., 2014. Identification of phosphate-solubilizing fungi from the asparagus rhizosphere as antagonists of the root and crown rot pathogen Fusarium oxysporum. Science Asia 40: 1620. Doi: 10.2306/scienceasia1513-1874.2014.40.016

Saeed, K.S., S.A. Ahmed, I. Hassan, P.H. Ahmed, 2015a. Effect of bio-fertilizer and chemical fertilizer on growth and yield in cucumber (Cucumis sativus) in green house condition. Pakistan Journal of Biological Sciences 18: 129-134. Doi: 10.3923/ pjbs.2015.129.134

Saeed, K.S., S.A. Ahmed, I.A. Hassan, N.J. Qader, 2015b. Comparison of different levels of phosphate and biofertilizer of growth and yield on tomato (Lycopersicum esculentum Mill) in green house condition. American-Eurasian Journal of Agricultural and 
Environmental Sciences 15: 210-215. Doi: 10.5829/idosi.aejaes.2015.15.2.12507

Sahoo, H.R., N. Gupta, 2017. Impact of three phosphate solubilizing species of Penicillium on growth of Piper longum L. under inoculated condition. Tropical Plant Research 4: 456-460. Doi: 10.22271/tpr.2017.v4.i3.060

Santoyo, G., M.D.C. Orozco-Mosqueda, M. Govindappa, 2012. Mechanisms of biocontrol and plant growth-promoting activity in soil bacterial species of Bacillus and Pseudomonas: a review. Biocontrol Science and Technology 22: 855-872. Doi: 10.1080/09583157.2012.694413

Schoebitz, M., M.D. López, H. Serrí, O. Martínez, E. Zagal, 2016. Combined application of microbial consortium and humic substances to improve the growth performance of blueberry seedlings. Journal of Soil Science and Plant Nutrition 16: 1010-1023. Doi: 10.4067/S0718-95162016005000074

Schulthess, B., G.V. Bloemberg, R. Zbinden, E.C. Böttger, M. Hombach, 2014. Evaluation of the Bruker MALDI Biotyper for identification of Gram-positive rods: development of a diagnostic algorithm for the clinical laboratory. Journal of Clinical Microbiology 52: 1089-1097. Doi: 10.1128/JCM.02399-13

Selvakumar, G., P. Joshi, S. Nazim, P. Mishra, J. Bisht, H. Gupta, 2009. Phosphate solubilization and growth promotion by Pseudomonas fragi CS11RH1 (MTCC 8984), a psychrotolerant bacterium isolated from a high altitude Himalayan rhizosphere. Biologia 64: 239-245. Doi: 10.2478/s11756-009-0041-7

Shanmugam, V., N. Kanoujia, 2011. Biological management of vascular wilt of tomato caused by Fusarium oxysporum f. sp. lycospersici by plant growth-promoting rhizobacterial mixture. Biological Control 57: 85-93. Doi: 10.1016/j.biocontrol.2011.02.001

Shanmugam, V., N. Kanoujia, M. Singh, S. Singh, R. Prasad, 2011. Biocontrol of vascular wilt and corm rot of gladiolus caused by Fusarium oxysporum f. sp. gladioli using plant growth promoting rhizobacterial mixture. Crop Protection 30: 807-813. Doi: 10.1016/j.cropro.2011.02.033

Sharma, S., A. Sharma, M. Kaur, 2018. Extraction and evaluation of gibberellic acid from Pseudomonas spp. plant growth promoting rhizobacteria. Journal of Pharmacognosy and Phytochemistry 7: 2790-2795.

Sharon, J.A., L.T. Hathwaik, G.M. Glenn, S.H. Imam, C.C. Lee, 2016. Isolation of efficient phosphate solubilizing bacteria capable of enhancing tomato plant growth. Journal of Soil Science and Plant Nutrition 16: 525-536. Doi: 10.4067/S071895162016005000043

Shen, Z., Y. Ruan, X. Chao, J. Zhang, R. Li, Q. Shen, 2015. Rhizosphere microbial community manipulated by 2 years of consecutive biofertilizer application associated with banana Fusarium wilt disease suppression. Biology and Fertility of Soils 51: 553562. Doi: 10.1007/s00374-015-1002-7

Singh, N.P., R.K. Singh, V.S. Meena, R.K. Meena, 2015. Can we use maize (Zea mays) rhizobacteria as plant growth promoter? Vegetos 28: 86-99. Doi: 10.5958/2229-4473.2015.00012.9

Smith, J.J., M.D. Lilly, R.I. Fox, 1990. The effect of agitation on the morphology and penicillin production of Penicillium chrysogenum. Biotechnology and bioengineering 35: 1011-1023. Doi: 10.1002/bit.260351009
Sood, G., R. Kaushal, A. Chauhan, S. Gupta, 2018. Indigenous plant-growth-promoting rhizobacteria and chemical fertilisers: impact on wheat (Triticum aestivum) productivity and soil properties in North Western Himalayan region. Crop and Pasture Science 69: 460-468. Doi: 10.1071/CP18016

Syed-Ab-Rahman, S.F., L.C. Carvalhais, P. Schenk, 2018. Identification of soil bacterial isolates suppressing different Phytophthora spp. and promoting plant growth. Frontiers in Plant Science 9: 1502. Doi: 10.3389/fpls.2018.01502

Thakkar, A., M. Saraf, 2015. Development of microbial consortia as a biocontrol agent for effective management of fungal diseases in Glycine max L. Archives of Phytopathology and Plant Protection 48: 459-474. Doi: 10.1080/03235408.2014.893638

Tomer, S., D.C. Suyal, R. Goel, 2016. Biofertilizers: A timely approach for sustainable agriculture. In: Choudhary, D., A. Varma, N. Tuteja (eds.), Plant-microbe interaction: An approach to sustainable agriculture. Springer, Singapore. Pp. 375-395. Doi: 10.1007/978981-10-2854-0_17

United Nations, 2010. United Nations Decade for Deserts and the Fight Against Desertification (UNDDD). Retrieved from https:// www.un.org/en/events/desertification_decade/whynow.shtml

Vessey, J.K., 2003. Plant growth promoting rhizobacteria as biofertilizers. Plant Soil 255: 571-586. Doi: 10.1023/A:1026037216893

Vurukonda, S.S.K.P., S. Vardharajula, M. Shrivastava, A. SkZ, 2016. Enhancement of drought stress tolerance in crops by plant growth promoting rhizobacteria. Microbiological Research 184: 13-24. Doi: 10.1016/j.micres.2015.12.003

Wang, C.J., W. Yang, C. Wang, C. Gu, D.D. Niu, H.X. Liu, Y.P. Wang, J.H. Guo, 2012. Induction of drought tolerance in cucumber plants by a consortium of three plant growth-promoting rhizobacterium strains. PLoS One 7: e52565. Doi: 10.1371/journal.pone.0052565

Wang, Y.Y., P.S. Li, B.X. Zhang, Y.P. Wang, J. Meng, Y.F. Gao, X.M. $\mathrm{He}, \mathrm{X.M} . \mathrm{Hu}, 2020$. Identification of phosphate-solubilizing microorganisms and determination of their phosphate-solubilizing activity and growth-promoting capability. BioResources 15 : 2560-2578. Doi: 10.15376/biores.15.2.2560-2578

Wasaya, A., X. Zhang, Q. Fang, Z. Yan, 2018. Root phenotyping for drought tolerance: a review. Agronomy 8: 241. Doi: 10.3390/ agronomy 8110241

Watts, J., 2018. Land degradation threatens human wellbeing, major report warns. Retrieved from https://www.theguardian.com/environment/2018/mar/26/land-degradation-is-undermining-human-wellbeing-un-report-warns

Widnyana, I.K., C. Javandira, 2016. Activities Pseudomonas spp. and Bacillus sp. to stimulate germination and seedling growth of tomato plants. Agriculture and Agricultural Science Procedia 9: 419-423. Doi: 10.1016/j.aaspro.2016.02.158

Xiao, C., R. Chi, H. He, G. Qiu, D. Wang, W. Zhang, 2009. Isolation of phosphate-solubilizing fungi from phosphate mines and their effect on wheat seedling growth. Applied Biochemistry and Biotechnology 159: 330-342. Doi: 10.1007/s12010-009-8590-3

Xiong, W., S. Guo, A. Jousset, Q. Zhao, H. Wu, R. Li, ... Q. Shen, 2017. Bio-fertilizer application induces soil suppressiveness against Fusarium wilt disease by reshaping the soil microbiome. Soil Biology and Biochemistry 114: 238-247. Doi: 10.1016/j.soilbio.2017.07.016 
Yadav, A.N., S.G. Sachan, P. Verma, A.K. Saxena, 2015. Prospecting cold deserts of north western Himalayas for microbial diversity and plant growth promoting attributes. Journal of Bioscience and Bioengineering 119: 683-693. Doi: 10.1016/j.jbiosc.2014.11.006

Yin, Z., F. Shi, H. Jiang, D.P. Roberts, S. Chen, B. Fan, 2015. Phosphate solubilization and promotion of maize growth by Penicillium oxalicum P4 and Aspergillus niger P85 in a calcareous soil. Canadian Journal of Microbiology 61: 913-923. Doi: 10.1139/cjm-2015-0358

Zhang, C., F. Kong, 2014. Isolation and identification of potassium-solubilizing bacteria from tobacco rhizospheric soil and their effect on tobacco plants. Applied Soil Ecology 82: 18-25. Doi: 10.1016/j.apsoil.2014.05.002 